\title{
Electronic Beam Technology in Optoelectronic Instrumentation: High-quality Curved Surfaces and Microprofile Creation in Different Geometric Shapes
}

\author{
I.V. Yatsenko, ,",V.P. Maslov², V.S. Antonyuk ${ }^{3}$, V.A. Vashchenkoํ, O.V. Kirichenko ${ }^{4}$, K.M. Yatsenko ${ }^{1}$ \\ 1 Cherkasy State Technological University, 460, Shevchenka Blvd., 18006 Cherkassy, Ukraine \\ ${ }^{2}$ V.E. Lashkaryov Institute of Semiconductor Physics NAS of Ukraine, 45, Nauky Ave., 02000 Kyiv, Ukraine \\ ${ }^{3}$ National Technical University of Ukraine "KPI", 37, Peremohy Ave., 03056 Kyiv, Ukraine \\ ${ }^{4}$ Cherkasy Institute of Fire Safety named after Chornobyl Heroes of National University of Civil Protection \\ of Ukraine, 8, Onoprienka St., 18034 Cherkasy, Ukraine
}

(Received 29 October 2020; revised manuscript received 15 August 2021; published online 20 August 2021)

\begin{abstract}
The curved surface treatment method of optical elements and functional microprofile creation of different geometric shapes using the system of fixed single electronic beams by optimizing the technological parameters of installation (the number of beams, their currents, accelerating voltages and distances to the processed surfaces) is developed. This method allows to create various microoptic parts for optoelectrical devices. The method is based on the practically implemented schemes of location of single electronic beam system that influence curved surfaces of optical elements. According to the developed method, the implementation task was solved using discretely located fixed sources of gaussian type thermal influence with different amplitudes (maximum values of electronic beam heat density) and focus factors influencing the processed surfaces of optical elements. At the same time, the impact control of such sources is carried out automatically using microprocessor equipment. It is shown that while increasing the number of electron rays (up to 50...70), you can get high accuracy of (relative error up to $10^{-4} \ldots 10^{-5}$ ) compliance with the specified complex distributed thermal influences along the processed both flat and curved optical elements necessary for the creation of functional microprofiles on their surfaces of a given geometric shape. At present, due to technical difficulties that are appearing, it is impossible to effectively manage a large number of beams (more than 10...15) However, reducing their number (for example, up to 5...7), it is possible to implement these distributed heat influences with an acceptable accuracy in practice (relative error does not exceed $3 \ldots .5 \%)$.
\end{abstract}

Keywords: Optoelectronic devices, Electronic beam, Optical element, Optimal control.

DOI: $10.21272 /$ jnep.13(4).04034

PACS number: 42.79.Bh

\section{INTRODUCTION}

In the conditions of modern development of optoelectronic and electronic instrumentation, the requirements for operational characteristics in optical elements of devices (surface microhardness, resistance to external thermal and mechanical shocks, etc.) are constantly increasing $[1,2]$.

In the result of practical research, it was proved that the most convenient, environmentally friendly and manageable way of processing optical elements is the electronic beam method of processing the surfaces of elements [3, 4].With the help of a moving electronic beam in a tape shape,one can get surfaces of high purity optical glass with minimal roughness (polishing of flat elements). However, the widespread use of a single electronic beam for the processing of curved surfaces of optical elements (concave, convex, cylindrical, spherical, etc.) is now facing irresistible difficulties [5].

This is due to the fact that for high-quality treatment of curved surfaces it is necessary to know the optimal laws of electronic beam parameters (density of heat exposure $F_{n}$, preservation coefficient $k$ (thermal impulse sharpness) and the travel speed $V$ ), providing in the process of treatment steady heat influence along the entire processed surface, otherwise, overheated areas on the surface will be necessarily formed, leading to cracks, lulls or zones of intense evaporation. At the same time, concave areas (so-called "inflows") and wavelike surfaces will occur on peripherical areas due to lower temperatures (intensive heat exchange with external environment). This, ultimately, will lead to disruption of the geometric shape inthe optical elements and their subsequent destruction.

At present, optimal realization task of the specified thermal effect with the help of a moving heat source has not been solvedi nfullyet. First of all, it concerns detecting the optimal law for measuring the movement speed of anelectronic beam during processing. This is due to the fact that such a task refers to complex nonlinear problems of optimal regulation of moving influence, the theoretical solution of which is currently absent, and there are only a few close enough numerical assessments of the optimal changing laws in the thermal effect movement speed.

A far more difficult task is to create,both on the flat and curved surfaces, optical elements of functional microprofilesin the a complex geometric shape with the help of a single movable electronicbeam. In this case, it is necessary to create not a uniform, but a complex distributed thermal effect along the elemental surface with the help of a single electronic beam. Reseache sin this direction are missing now .

The purpose of the work is to develop the processing method of the curvilineal surfaces in optical elements and to create for them functional microprofiles of differ- 
ent geometric shapes bynonmovable single electronicbeam system.

\section{INVESTIGATION RESULTS AND THEIR ANALYSIS}

The method is based on the practically realized location schemes of a single electron beam system, affecting curvilinear surfaces in optical elements (see Fig. 1 andFig. 2).
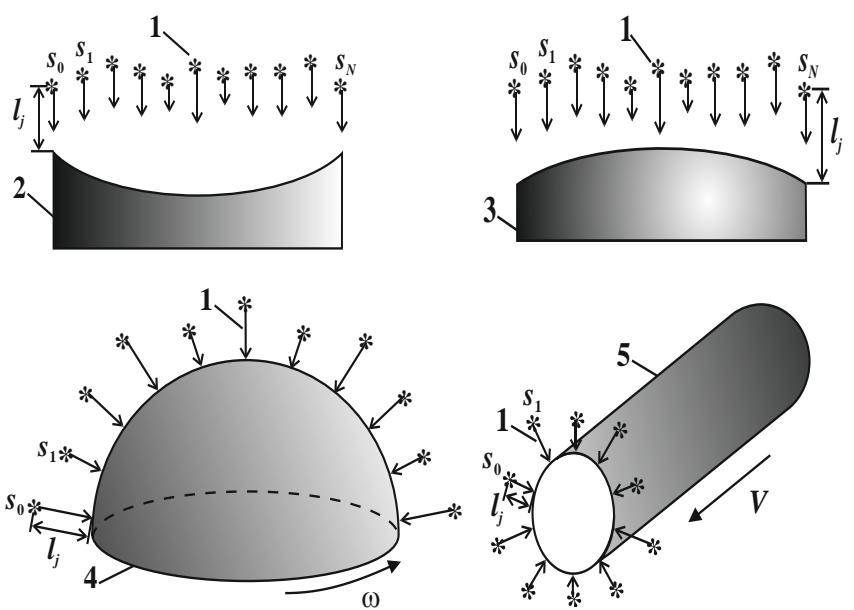

Fig. 1 - Schematic representation of the processing of curved surfaces of optical elementswith the help of a discreetly located non-movable electronicbeam system (1): concave (2) and convex (3) surfaces, hemispherical(4) and cylindrical (5) surfaces; $s_{0}, s_{1}, \ldots-$ a system of single electronicbeams, which are located at different distances $l_{j}(j=0,1, \ldots)$ from the treated surface; $\omega, V$ is an angular speed of rotation of ahemisphericalelement and the feeding speed of a cylindrical element into the processed area, that provide specified distributed thermal effects on their surfaces

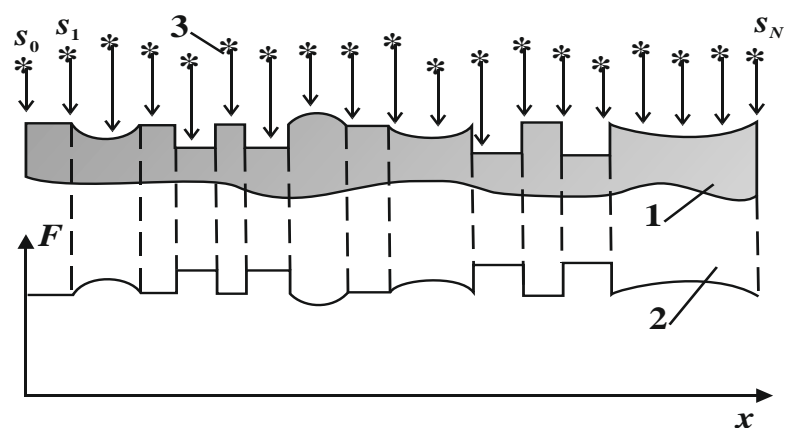

Fig. 2- Schematic representation of the method of creating functional microprofiles on the optical element surface of a complex geometric shape using a system of discretely spaced fixed electronic beams: 1 - a given microprofile on the surface of an element, which must be obtained by its processing with the help of a single electronic beam system $s_{0}, s_{1}, \ldots, s_{n}$ with different parameters; 2 - difficultly distributed thermal effect along the surface of element $F(x)$, which must be implemented by optimizing beam parameters and their number

Realization task of the specified thermal influences along the processed surface of the optical element with the help of a system of single fixed electronic beams. According to the developed method, the implementation task was solved using discretely located fixed thermal effect sources of gaussian type (Fig. 3) with different amplitudes (maximum values of electronic beam thermal effect density $\left.F_{n j}, j=\overline{1, N}\right)$ and focus coefficients $k_{j}$ ( $j=\overline{1, N}$ ), affecting the processed surfaces of optical elements. At the same time, the control of the influence of such sources is carried outautomatically by using microprocessor technology.

Setting the problem. This above mentioned approach requires a transition in solving realization problems from continuous to discrete power distribution with the respect of the processed surface, i.e. determining number $N$ of discretely distributed energy sources, as well as the locations of these sources.

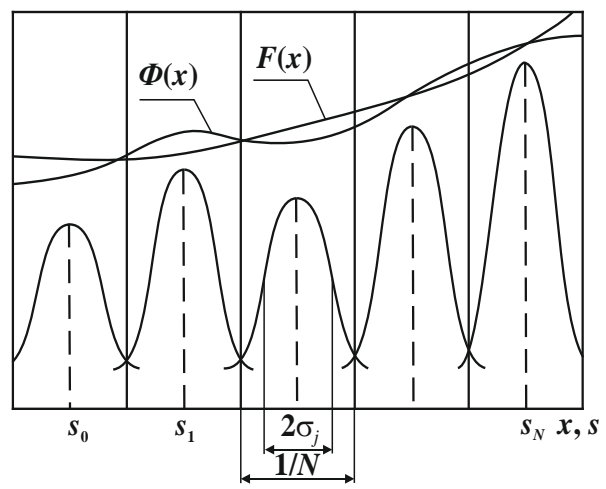

Fig. 3--Schematic representation of approximation to the given distributed thermal effec $F(x)$ along the surface of the optical element by a set of discretely spaced fixed sources $s_{j}$ ( $j=\overline{1, N}$ ) of the gaussian type thermal effect $\Phi(x)$

This implementation task will be solved with the following assumptions.

1. One-dimensional setting of the problem.

2. Power distribution with respect to the coordinate $x$ along the processed surface for every discrete source $j$ of thermal effect (electronic beam) is described by Gauss law [6, 7]:

$$
\phi_{j}(x)=\frac{1}{(2 \pi)^{1 / 2} \cdot \sigma_{j}} \cdot e^{-\frac{\left(x-s_{j}\right)^{2}}{2 \sigma_{j}^{2}}}
$$

where $\sigma_{j}^{2}=\frac{1}{2 k_{j}}-$ dispersion.

Then the total power density in a fixed point $x_{j}$ of segment $j$ will stand for a sum of $\phi_{j}(x)$ on all $N$ sources:

$$
\Phi(x)=\sum_{j=1}^{N} \phi_{j}(x)=\frac{1}{(2 \pi)^{1 / 2}} \sum_{j=1}^{N} \frac{e^{-\frac{\left(x-s_{j}\right)^{2}}{2 \sigma_{j}^{2}}}}{\sigma_{j}}
$$

3. We will consider the normalized values of distributed power that need to be realized (the total energy contribution that is the same for different types of distributed power), and the coordinate of the length - in a dimensionless form:

$$
\int_{0}^{1} F(x) d x=1
$$


4. The distribution of discrete sources along the entire length of the segment is uniform, that is, the distance from the maximum impulse $j$ to the maximum impulse $j+1$ is fixed and equals $1 / N$.

Thus, the task is to determine the number of discrete sources $N$ and the parameters for each of them $\sigma_{j}(j=\overline{1, N})$, so that the approximation of $F(x)$ by the function $\Phi(x)$ would be better in some norm

$$
I=\|\Phi(x)-F(x)\| \rightarrow \min
$$

that is presented in the common formalized pattern [6, 7] towards the considered task:

$$
s=\sum_{i=1}^{M}\left[\frac{1}{(2 \pi)^{1 / 2}} \sum_{j=1}^{N} \frac{e^{-\frac{\left(x_{i}-s_{j}\right)^{2}}{2 \sigma_{j}^{2}}}}{\sigma_{j}}-F\left(x_{i}\right)\right]^{2} \rightarrow \min _{N, \sigma_{j}}
$$

The value of $N$ is determined by two factors. First, by a sufficient accuracy of the function approximation $\Phi(x)$ (leads to an increase in $N$ ), and secondly, the possibility of technical implementation of a discrete source. Since $N$ can be large enough (several dozen), the formulated task (5) is multi-dimensional. To overcome the computational difficulties associated with the dimension of the task, we will use the standard optimization method, which has proven itself well for large-scale tasks. The core of the method presupposes that a function is searched as a solution, which approximates it by the spatial coordinate. If nothing is known about the outage of the functional solution, then its approximation is searched in the class of polynomials, consistently raising the degree as long as the sum value $S$ of the square binding falls. With this approach, variated variables will stand for the parameters of the function (polynom coefficients), which are always less in their number than the number of output independent variables. If any restrictions (such as equalities) are imposed on the approximated function, the number of independent variables can still be reduced by the number of relationships. In our particular case, we will search not $\sigma_{j}(j=\overline{1, N})$, but for the coefficients of the polynom

$$
\sigma_{j}=x(1)+x(2) j+x(3) j^{2}+\ldots+x(n) j^{n-1}
$$

which describes the distribution $\sigma_{j}$ by the degrees of the number of the je-relay (by pulses).

Now the task is not to find a dozen values of $\sigma_{j}$ that minimize the sum of squares of evasionsin the given and approximating function for a fixed $N$, but in determining $2 \ldots .5$ coefficients of polynomium (6), solving the same task with good accuracy.

To find the optimal coefficient values of the approximant polynomium (6), you need to use the standard searching method of nonlineary optimization. This is due to the fact that the calculation of the minimized functiongradient, and, moreover,Hesse matrix (the second derivatives) is quite ambiguous, and, in addition, the presence of the so-called "cavities" is not excluded in the used form of approximating function - all this requires the choice of the most effective methods of numerical optimization in the function of some considered variables.A specialized package of applications [4, $5,11]$ was used on purpose, which contains the most effective methods of numerical optimization in various functions and which allow varying input, choose the most appropriate method of optimization in the dialog mode.

According to this approach, the general algorhythm pattern of task solving is the following.

The role of the main programis given to the program of the numerical optimization method (basically, it is Rosenbrok method types[6]). In this case, the keyboard sets the value of the number of varied variablesN1, the value of the start point coordinates $X(1), X(2), \ldots, X(N 1)$ in the main program PROGRO andsubprogram PROGR1, which calculates the target function, as well as the values are assigned, which are the number of single sources $N$ and the numberdiscretization nodes $M 1$ in the length coordinates. The CALL operator (line 15) calls thesubprogram PROGR1 to count the targetfunction $\Phi 1$ at the starting point.After returning to the main program, the coordinate values of the next point are formed, and again there is a transition to the subprogram PROGR1 to count the target function $\Phi$ at the formed point (line 30). The result of $\Phi 1$ and $\Phi$ comparison determines the subsequent movement to the optimum in accordance with the selected numerical method.

It should be mentioned that the main program PROGRO is executed as a standard and can be used in other tasks. Subprogram PROGR1 is a part of the specified changing program, thus $X$ is the variation vector, ETA1is the target function value being calculated.

The analysis of the results shows that for the evenly distributed power of the thermal effect source on the processed surface of the product we receive the following solutions at two single sources of Gauss type, that implement a given distributed thermal effect: $X(1)=0.7161, \quad X(2)=-0.04943, \quad X(3)=-1.8461 \cdot 10^{-3}$, $s=0.0732$; at five single sources: $X(1)=1.2205$, $X(2)=0.39, \quad X(3)=0.362, s=0.0216$; at eight single sources: $X(1)=-0.015, X(2)=3.06, \quad X(3)=-1,5 \cdot 10^{-3}$, $s=0.01137$; at ten single sources: $X(1)=3.9707$, $X(2)=-0.015, \quad X(3)=-1.5 \cdot 10^{-3}, s=9.5 \cdot 10^{-5}$. At the same time, no further increase in the number of single sources was carried out, because the accuracy of approaching $s \cong 10^{-4}$ is quite sufficient for practical calculations (corresponds to the average quadratic error of approximation $\cong 0.11 \%$ ).

The results of calculations for other, more complex power distributions of thermal effect on the processed surface of the product show that the specified accuracy can also be achieved by an acceptable number of steps, but with many more used single sources: with hyperbolically distributed power of $40 \ldots 50$ sources, and with a wide gaussian power distribution of $50 \ldots 70$ sources.

It is necessary to point out that for anysource $j$ of the thermal effect the focus factor $k_{j}=\frac{1}{2 \sigma_{j}}$ (impulse effect acuity) and amplitude (density of thermal effect in the 
center of $\left.F_{n}=\phi_{j \max }=\frac{1}{(2 \pi)^{1 / 2} \cdot \sigma_{j}}\right)$ is calculated on the basis of simple formulae (5) and (6).

Thus, by increasing the number of electron beams (up to 50...70), you can get high accuracy (relative error up to $10^{-4} \ldots 10^{-5}$ ) of correspondence in the specified complex distributed thermal effects along the processed flat and curvilinear optical elements necessary for the development of functional microprofiles on their surfaces of a given geometric shape.

It should be noted that now due to the technical difficulties that appear, it is impossible to effectively manage a large number of beams (more than 10...15) [11]. However, reducing their number (for example, up to 5...7), it is possible to implement these distributed thermal effects with acceptable accuracy in practice (relative error does not exceed $3 . .5 \%$ \%).

For the technical implementation of the developed method, it is necessary to link the determined optimal parameters $\phi_{j \max }$ and $k_{j}(j=\overline{1, N})$ with the controlled technological parameters of the electronic beam installation (beam currents $I_{n j}$, accelerating voltages $V_{y j}$ and distances to the processed surfaces), which are behind beam sensing results:

$$
\begin{gathered}
\phi_{j \max }=\frac{I_{n j} \cdot V_{y j}}{\sqrt{\pi} \cdot \operatorname{erf}\left(a_{i j}\right)} \cdot \sqrt{k_{j}\left(I_{n j}, l_{j}\right)}, \\
k\left(I_{n}, l\right)=a_{0 j}+a_{1 j} \cdot l_{j}+a_{2 j} \cdot I_{n j}+a_{3 j} \cdot I_{s j} \cdot l_{j}, j=\overline{1, N},
\end{gathered}
$$

where $a_{i j}(i=\overline{0,4})$ - empirical constants.

After that, by using the obtained dependences (7) and (8), we can technically implement the developed method in the form of an automated process control system (APCS) of electronic beam treatment of surfaces in optical elements of different geometric shapes and creation off unctional profiles on them using the system of static and discretely distributed electronic beams, which can be used as an elemental base in microoptics, integrating and fiber optics and other branches of optoelectronic instrumentation and construction.

To sum it all up, it should be mentioned that, as a practice has shown, in the spotlight of the latest technologies used in optoelectronic instrumentation, electron beam processing of elements made of optical glass and ceramics, elements of piezoceramics, as well as optical elements with abnormal and dimensional coatings of metal oxides is determined as potentially capable of high-quality processing of flat and curved surfaces, obtaining functional microprofiles on their surfaces using electronic beams that can be used as an elemental base in microoptics, thermal and fiber optics, optoelectronics, functional electronics and other areas of precise instrumentation. In addition, the undeniable advantages of electronic beam technology are its ecological purity and the ability to obtain, on a common board from the optical material in a single technological cycle,microelements with improved operational characteristics, the use of which in optical details of optoelectrical devices contributes to their non-failure work in exploitation and location.

\section{CONCLUSIONS}

A new scientifically proved method was developed which stands for electronic beam processing of curved surfaces of optical elements and functional microprofiles formation of different geometric shapes using the system of fixed discretely spaced electronic beams by optimizing the technological parameters of installation (number of beams, their currents, accelerating voltages and distances to the processed surfaces), that allows to create various microoptic parts for optoelectrical devices.

\section{REFERENCES}

1. A.R. Glushchenko, V.I. Gordiyenko, A.A. Burkovskiyi et al., Lazernyye sistemy tankouykh pritselov (Maklaut: Cherkassy: 2009) [In Russian].

2. T.I. Hural', V.M. Tyahur, N.I. Lykholit, N.I. Ovchar, N.E. Kyrylyuk, Spetsial'ne pryladobuduvannya: stan ta perspektyvy: Zbirnyk tez dopovidey 2-yi Ukrayins'koyi naukovo-tekhnichnoyi konferentsiyi, 63 (KP SPB "Arsenal": Kyiv: 2016) [In Russian].

3. V.A. Vashchenko, I.V. Yatsenko, Yu.I. Kovalenko, V.P. Kladko, O.Yo. Gudymenko, P.M. Lytvyn, A.A. Korchovyi, S.V. Mamykin, O.S. Kondratenko, V.P. Maslov, H.V. Dorozinska, G.V. Dorozinsk, Effect of electron-beam treatment of sensor glass substrates for SPR devices on their metrological characteristics, 22 No 4, 444 (SPQEO:

2019).

4. I.V. Yatsenko, V.S. Antonyuk, V.A. Vashchenko, O.V. Kyrychenko, O.M. Tishchenko, J. Nano- Electron. Phys.11 No 2, 02014 (2019).

5. I. Yatsenko, V. Antoniuk, O. Kiritchenko, V. Vashchenko, Int. J. Sci. Innov. Industry "Machines. Technologies. Materials"1, 20 (2017).

6. I.V. Yatsenko, S.V. Antonyuk, V.A. Vaschenko, V.V. Tsybulin, J. Nano- Electron. Phys. 8 No 1, 01027 (2016).

7. V.A. Vashchenko, I.V. Yatsenko, YU.H. Leha, O.V. Kyrychenko, Osnovy elektronnoyi obrobky vyrobiv $z$ optychnykh materialiv. Monohrafiya (Naukovadumka: Kyiv: 2011) [In Ukrainian]. 


\title{
Електронно-променева технологія в оптоелектронному приладобудуванні: високоякісні криволінійні поверхні та створення мікропрофілів різної геометричної форми
}

\author{
І.В. Яценко ${ }^{1}$, В.П. Маслов², В.С. Антонюк ${ }^{3}$, В.А. Ващенко ${ }^{1}$ О.В. Кириченко ${ }^{4}$, К.М. Яценко ${ }^{1}$
}

1 Черкаський державний технологічний університет, бульв. Шевченка, 460, 18006 Черкаси, Україна

${ }^{2}$ Інститут фбізики напівпровідників ім. В.Є. Лашкарьова, просп. Науки, 45, 02000 Київ, Україна

${ }^{3}$ Національний технічний університет Украӥни "Київський політехнічний інститут імені Ггоря Сікорського", просп. Перемоги, 37, 03056 Київ, Україна

4 Черкаський інститут пожежної безпеки імені Героїв Чорнобиля Національного університету цивільного захисту Украӥни, вул. Онопрієнка, 8, 18034 Черкаси, Україна

\begin{abstract}
Розроблено метод обробки криволінійних поверхонь оптичних елементів та створення на них функціональних мікропрофілей різної геометричної форми за допомогою системи нерухомих одиничних електронних променів шляхом оптимізації технологічних параметрів установки (кількості променів, їх струмів, прискорюючихнапруг та відстаней до оброблюваних поверхонь), що дозволяе створювати різні мікрооптичні деталі для оптико-електронних приладів. В основу методу покладені реалізовані на практиці схеми розташування системи одиничних електронних променів, що діють на криволінійні поверхні оптичних елементів. Згідно розробленого метода задача реалізації вирішувалась за допомогою дискретно розташованих нерухомих джерел теплового впливу гаусівського типу з різними амплітудами (максимальні значення густини теплового впливу електронних променів) та коефіцієнтами зосередженості , що діють на оброблювані поверхні оптичних елементів. При цьому керування впливом таких джерел здійснюеться автоматично з використанням мікропроцесорної техніки. Показано, що збільшуючи кількість електронних променів (до 50...70) можна отримати високу точність (відносна похибка до $10^{-4} \ldots 10^{-5}$ ) відповідності заданим складним розподіленим тепловим впливам вздовж оброблюваних як плоских, так й криволінійних оптичних елементів, необхідних для створення функціональних мікропрофілей на їх поверхнях заданої геометричної форми. Нині внаслідок технічних труднощів, які вникають, неможливо здійснювати ефективне керування великою кількістю променів (більше 10...15) Однак, зменшуючи їх кількість (наприклад, до 5...7), можна реалізовувати вказані розподілені теплові впливи з прийнятною на практиці точністю (відносна похибка не перевищуе $3 \ldots 5$ \%).
\end{abstract}

Ключові слова: Оптико-електронні прилади, Електронний промінь, Оптичний елемент, Оптимальне керування. 